\title{
PENENTUAN WAKTU OPTIMUM PRODUKSI METABOLIT SEKUNDER ISOLAT BAKTERI Actinomycetes DARI TANAH RHIZOSFER AKAR TANAMAN JARAK PAGAR (Jatropha curcas L) TERHADAP BAKTERI PATOGEN
}

\author{
Fitriana, Rusli \\ Fakultas Farmasi Universitas Muslim Indonesia \\ Email : fitriana.fitriana@umi.ac.id
}

\begin{abstract}
The study of optimum time determination of secondary metabolite production of Actinomycetes bacteria isolate from Jatropha curcas $L$ root of the soil (Jatropha curcas (L) of pathogenic bacteria has been done with the aim to determine pathogen bacteria that can be inhibited by Actinomycetes bacteria and determine the optimum time in producing secondary metabolite to pathogenic bacteria. The first phase of this study is to isolate Actinomycetes purification IBPT 01. Then performed a screening test of activity against pathogenic bacteria. Furthermore, the timing of production of antibiotics or secondary metabolites with bacterial fermentation Actinomycetes IBPT 01 begins on the 1st day until the 28th day and carried out the activity of antibiotics for 28 days. The results obtained in the screening test Actinomycetes bacteria activity IBPT code 01 provides antibacterial activity with category which has a diameter of 20 $\mathrm{mm}$ 11- barriers against 8 bacteria while one bacterium with diameter $>20 \mathrm{~mm}$ including strong category. Optimization results showed that the isolated bacteria Actinomycetes capable of producing secondary metabolites on 9 day, 8 day, 7 day, 4 day and 26 day. From this research can be concluded that the bacterial isolates of Actinomycetes IBPT 01 can provide the optimum time to produce different secondary metabolites.
\end{abstract}

Key words: Actinomycetes, secondary metabolite, optimum time.

\section{PENDAHULUAN}

Penemuan sumber-sumber antibiotik baru di alam dilakukan dengan cara penapisan atau skrining untuk menemukan mikroorganisme penghasil antibiotik, termasuk tanah dari berbagai tempat diuji kemampuan potensialnya dalam menghasilkan antibiotik. Proses penapisan ini terdiri dari dua tahap yaitu skrining primer yang dimulai dari mengisolasi sumber penghasil dan menguji hasil isolat yang diperoleh dan skrining sekunder, salah satunya mencari kondisi optimal untuk pertumbuhan dari hasil isolat yang telah diperoleh. ${ }^{1}$

Saat ini banyak dikembangkan penelitian penghasil antibiotik, salah satunya dari Actinomycetes. Actinomycetes berhabitat di dalam 
Penentuan waktu optimum produksi metabolit sekunder isolat bakteri Actinomycetes dari tanah rhizosfer akar tanaman jarak pagar (Jatropha curcas $L$ ) terhadap bakteri patogen

tanah serta tersebar luas di tanah. ${ }^{2}$ Selain itu banyak juga terdapat di dalam air dan berasosiasi dengan tanaman tingkat tinggi. Actinomycetes merupakan suatu penghasil senyawa aktif terbanyak dibandingkan dengan bakteri atau kapang, baik itu senyawa aktif sebagai antimikroba, antikanker, antivirus, maupun antikolesterol. ${ }^{3}$

Penelitian yang telah dilakukan oleh Intan Husaepa, memperoleh hasil isolasi bakteri Actinomycetes dari tanah rizosfer akar tanaman jarak pagar (Jatropha curcas. L) yang berasal dari Kecamatan Patalassang Kabupaten Takalar diperoleh sebanyak 6 isolat bakteri Actinomycetes dan diperoleh 2 isolat bakteri Actinomycetes dengan kode isolat bakteri IBPT 01 dan IPBT 04 yang memberikan aktivitas terhadap beberapa bakteri patogen. ${ }^{4}$ Untuk isolat bakteri IBPT 04 telah diperoleh hasil optimum dalam memproduksi antibiotik pada hari ke 18 sedangkan isolat bakteri IBPT 01 belum dilakukan pengujian lanjutan.

Berdasarkan uraian diatas, maka perlu dilakukan penelitian lanjutan untuk isolat bakteri IBPT 01 yaitu penentuan waktu optimum produksi metabolit sekunder isolat bakteri Actinomycetes dari tanah rizosfer akar tanaman jarak pagar (Jatropha curcas. L) terhadap bakteri patogen. Waktu optimum produksi metabolit sekunder berupa antibiotik dilakukan dengan cara fermentasi menggunakan media yeast maltose ekstrak broth dan ditetapkan dengan menentukan aktivitas antibakteri tertinggi yang ditimbulkan oleh filtrat hasil fermentasi. Pengujian aktivitas antibakteri dilakukan menggunakan metode difusi agar terhadap bakteri patogen.

\section{METODE PENELITIAN}

\section{Alat dan bahan}

Alat yang digunakan adalaha autoklaf (SMIC Model YX-280 B), alat gelas, inkubator (Memert), Laminar Air Flow (LAF), oven (Memert), analitik (Chyo), tabung ependorf dan vial. Bahan-bahan yang digunakan pada penelitian ini adalah aquadest, Bakteri patogen (Bacillus subtilis, Pseudomonas aeruginosa, Salmonella typhi NCTC 786, Shygella dysentriae, Staphylococcus aureus ATCC 2592,3 Staphylococcus epidermidis, Streptococcus mutans, Vibrio cholerae dan Escherichia coli ATCC 25922), medium Muller Hinton Agar (MHA), medium Starch Casein Agar (SCA) (Casein powder, Starch, Agar), Medium Fermentasi (Soybean powder, sucrosa, soluble starch, yeast ekstrak, protease pepton, $\mathrm{NaCl}, \mathrm{CaCO}_{3}, \mathrm{MgSO}_{4} .7 \mathrm{H}_{2} \mathrm{O}$, $\left.\mathrm{KH}_{2} \mathrm{PO}_{4}\right), \mathrm{NaCl}$ fisiologi $0,9 \%$ dan 
Penentuan waktu optimum produksi metabolit sekunder isolat bakteri Actinomycetes dari tanah rhizosfer akar tanaman jarak pagar (Jatropha curcas $L$ ) terhadap bakteri patogen

Isolat Bakteri Aktinomycetes dari tanah rizosfer akar tanaman jarak pagar kode IBPT 01.

\section{Prosedur kerja}

Pemurnian isolat bakteri

\section{Actinomycetes}

Isolat Bakteri Actinomycetes dengan kode IBPT 01 ditumbuhkan pada medium Starch Casein Agar (SCA) yang baru dengan menggunakan metode kuadran. Isolat bakteri Actinomycetes diambil dengan menggunakan jarum ose gores, kemudian digoreskan pada kuadran pertama. Jarum ose disterilkan, ujung dari penggoresan pertama kemudian diteruskan dengan menariknya pada kuadran kedua dan digores kembali. Begitu seterusnya hingga kuadran ke4. Isolat bakteri Actinomycetes yang tumbuh terpisah di kuadran 4 diremajakan pada medium SCA miring sebagai isolat murni untuk digunakan pada pengujian selanjutnya. ${ }^{4}$

\section{Penyiapan Bakteri Patogen}

Mikroba uji berupa Bacillus subtilis, Escherichia coli ATCC 25922, Pseudomonas aeruginosa, Salmonella typhi NCTC 786, Shygella dysentriae, Staphylococcus aureus ATCC 2592, Staphylococcus epidermidis, Streptococcus mutans, dan Vibrio cholerae, masing-masing diambil satu ose lalu diinokulasikan dengan cara digoreskan pada medium NA miring, diinkubasikan selama 1×24 hari pada suhu $37^{\circ} \mathrm{C} .^{5}$

Mikroba hasil peremajaan, masing-masing disuspensikan dengan larutan $\mathrm{NaCl}$ fisiologi 0,9\% sampai diperoleh transmitan $25 \% \quad \mathrm{~T}$ menggunakan spektrofotometer dengan panjang gelombang $580 \mathrm{~nm}$ sebagai blanko digunakan $\mathrm{NaCl}$ fisiologi $0,9 \% .^{5}$

Uji skrining isolat bakteri

\section{Aktinomycetes}

Pemeriksaan aktivitas yang umum dilakukan ialah cara difusi agar dengan menggunakan medium MHA. Disiapkan suspensi bakteri uji diinokulasikan 20 ul suspensi bakteri uji ke dalam cawan petri tersebut, lalu dituang $10 \mathrm{ml}$ medium $\mathrm{MHA}$, isolat bakteri Aktinomycetes yang tumbuh dipotong kecil sekitar $0,5 \mathrm{~cm} \times 0,5 \mathrm{~cm}$ kemudian potongan tersebut di letakkan diatas medium agar yang telah diinokulasi dengan bakteri uji, setelah itu diinkubasi selama $1 \times 24$ hari pada suhu $37^{\circ} \mathrm{C}$, dan diamati dan diukur zona hambatan yang terbentuk. ${ }^{6}$

Pembuatan kultur isolat bakteri Aktinomycetes

Pembuatan starter dengan cara memasukkan 1 koloni isolat Actynomycetes ke dalam erlenmeyer yang berisi medium Fermentasi 
Penentuan waktu optimum produksi metabolit sekunder isolat bakteri Actinomycetes dari tanah rhizosfer akar tanaman jarak pagar (Jatropha curcas $L$ ) terhadap bakteri patogen

sebanyak $50 \mathrm{~mL}$ yang sudah disterilkan. Kultur starter diinkubasi pada suhu $27^{\circ} \mathrm{C}$ selama 5 hari. $^{7}$

\section{Fermentasi isolat bakteri}

\section{Aktinomycetes}

Preparasi isolat bakteri dilakukan dengan cara memasukkan $10 \mathrm{~mL}$ starter ke dalam erlenmeyer yang berisi $450 \mathrm{~mL}$ medium Fermentasi yang sudah disterilkan. Selanjutnya dilakukan fermentasi selama 28 hari dengan menggunakan shaker dengan kecepatan 200 rpm. Selama proses fermentasi, setiap hari diambil $1 \mathrm{~mL}$ kultur dan dimasukkan ke dalam tabung eppendorf dan diberi label, untuk pengujian selanjutnya. ${ }^{7}$

\section{Pengujian aktivitas antibiotik}

Petri yang berisi medium NA diolesi secara merata dengan suspensi bakteri uji. Setelah itu dibuat sumuran pada medium MHA, sebanyak $50 \mu \mathrm{L}$ cairan fermentat yang diambil selama 28 hari dimasukkan ke dalam sumuran sesuai dengan urutan harinya dan diinkubasi pada $37{ }^{\circ} \mathrm{C}$ selama $18-24$ hari untuk diamati diameter zona hambatnya. Profil optimasi waktu produksi metabolit sekunder dibuat berdasarkan hubungan antara waktu fermentasi dan diameter zona hambat. ${ }^{7}$

\section{HASIL PENELITIAN}

Tabel 1. Hasil Uji Skrining Isolat Actinomycetes kode IBPT 01 terhadap bakteri patogen.

\begin{tabular}{|c|c|c|c|c|c|}
\hline \multirow{2}{*}{ No. } & \multirow{2}{*}{ Bakteri Uji } & \multicolumn{4}{|c|}{ Diameter Zona Hambatan } \\
\cline { 3 - 6 } & & $\mathbf{1}$ & $\mathbf{2}$ & $\mathbf{3}$ & $\mathbf{r}$ \\
\hline 1 & Bacillus subtilis & 15,86 & 13,81 & 13,42 & 14,36 \\
\hline 2 & Escherichia coli & 18,1 & 18,11 & 18,06 & 18,09 \\
\hline 3 & Pseoudomnas aeruginosa & 17,62 & 14,13 & 15,53 & 15,76 \\
\hline 4 & Staphylococcus aureus & 15,28 & 15,73 & 13,68 & 14,90 \\
\hline 5 & Staphylococcus epidermidis & 16,1 & 15,55 & 14,77 & 15,47 \\
\hline 6 & Shigella dysentriae & 13,68 & 12 & 12,2 & 12,63 \\
\hline 7 & Streptococcus mutans & 21,93 & 23,26 & 22,04 & 22,41 \\
\hline 8 & Salmonella thypii & 12,9 & 13,47 & 12,11 & 12,83 \\
\hline 9 & Vibrio cholerae & 15,87 & 16,01 & 15,93 & 15,94 \\
\hline
\end{tabular}

Tabel 2. Hasil pengujian aktivitas antibakteri setiap waktu produksi 24 hari 
Penentuan waktu optimum produksi metabolit sekunder isolat bakteri Actinomycetes dari tanah rhizosfer akar tanaman jarak pagar (Jatropha curcas $L$ ) terhadap bakteri patogen

\begin{tabular}{|c|c|c|c|c|c|c|c|c|c|c|}
\hline \multirow{2}{*}{ No } & \multirow{2}{*}{$\begin{array}{l}\text { Hari } \\
\text { ke- }\end{array}$} & \multicolumn{9}{|c|}{ Diameter Zona Hambatan (mm) } \\
\hline & & $\begin{array}{c}\text { B. } \\
\text { subtilis }\end{array}$ & $\begin{array}{c}E . \\
\text { coli }\end{array}$ & $\begin{array}{c}P . \\
\text { aeruginosa }\end{array}$ & $\begin{array}{c}\text { S. } \\
\text { aureus }\end{array}$ & $\begin{array}{c}\text { S. } \\
\text { dysentriae }\end{array}$ & $\begin{array}{c}\text { S. } \\
\text { epidermidis }\end{array}$ & $\begin{array}{c}\text { S. } \\
\text { mutans }\end{array}$ & $\begin{array}{c}\text { S. } \\
\text { thypii }\end{array}$ & $\begin{array}{c}\text { V. } \\
\text { cholerae }\end{array}$ \\
\hline 1 & 1 & 6,00 & 6,00 & 6,00 & 6,00 & 6,00 & 6,00 & 6,00 & 6,00 & 6,00 \\
\hline 2 & 2 & 6,79 & 8,55 & 8,41 & 8,21 & 7,53 & 7,61 & 7,56 & 8,98 & 7,52 \\
\hline 3 & 3 & 6,00 & 7,41 & 6,00 & 7,35 & 6,93 & 6,18 & 6,40 & 6,71 & 6,00 \\
\hline 4 & 4 & 8,48 & 6,63 & 8,84 & 8,50 & 6,93 & 6,17 & 6,81 & 8,67 & 6,59 \\
\hline 5 & 5 & 6,00 & 7,83 & 6,00 & 6,00 & 6,00 & 6,00 & 17,06 & 6,00 & 6,00 \\
\hline 6 & 6 & 21,89 & 7,30 & 6,00 & 6,00 & 6,00 & 6,00 & 6,00 & 6,00 & 6,00 \\
\hline 7 & 7 & 20,32 & 23,07 & 24,60 & 6,00 & 23,42 & 20,58 & 6,00 & 26,72 & 10,71 \\
\hline 8 & 8 & 23,92 & 23,12 & 22,74 & 6,00 & 21,74 & 21,01 & 20,69 & 23,33 & 6,00 \\
\hline 9 & 9 & 25,83 & 18,67 & 23,54 & 6,00 & 6,00 & 6,00 & 6,00 & 17,83 & 6,00 \\
\hline 10 & 10 & 22,87 & 6,00 & 6,00 & 6,00 & 6,00 & 6,00 & 6,00 & 20,73 & 6,00 \\
\hline 11 & 11 & 6,00 & 6,00 & 6,00 & 6,00 & 6,00 & 6,00 & 6,00 & 6,00 & 7,96 \\
\hline 12 & 12 & 6,00 & 6,00 & 6,00 & 6,00 & 6,00 & 6,00 & 6,00 & 6,00 & 6,00 \\
\hline 13 & 13 & 6,00 & 6,00 & 6,00 & 6,00 & 6,00 & 9,03 & 6,00 & 6,00 & 8,33 \\
\hline 14 & 14 & 6,00 & 6,00 & 6,00 & 6,00 & 6,00 & 6,00 & 6,00 & 6,00 & 6,00 \\
\hline 15 & 15 & 6,00 & 6,00 & 6,00 & 6,00 & 6,00 & 6,00 & 6,00 & 6,00 & 6,00 \\
\hline 16 & 16 & 6,00 & 6,00 & 6,00 & 6,00 & 6,00 & 6,00 & 6,00 & 6,00 & 6,00 \\
\hline 17 & 17 & 6,00 & 6,00 & 6,00 & 6,00 & 6,00 & 6,00 & 6,00 & 6,00 & 6,00 \\
\hline 18 & 18 & 6,00 & 6,00 & 6,00 & 6,00 & 6,00 & 6,00 & 26,20 & 6,00 & 6,00 \\
\hline 19 & 19 & 6,00 & 6,00 & 6,00 & 6,00 & 6,00 & 6,00 & 6,00 & 6,00 & 8,88 \\
\hline 20 & 20 & 6,00 & 6,00 & 6,00 & 6,00 & 6,00 & 6,00 & 25,73 & 6,00 & 8,27 \\
\hline 21 & 21 & 6,00 & 6,00 & 6,00 & 6,00 & 6,00 & 6,00 & 6,00 & 6,00 & 8,49 \\
\hline 22 & 22 & 6,00 & 6,00 & 6,00 & 6,00 & 6,00 & 6,00 & 6,00 & 6,00 & 6,00 \\
\hline 23 & 23 & 6,00 & 6,00 & 6,00 & 6,00 & 6,00 & 6,00 & 6,00 & 6,00 & 8,76 \\
\hline 24 & 24 & 6,00 & 6,00 & 6,00 & 6,00 & 6,00 & 6,00 & 6,00 & 6,00 & 8,87 \\
\hline 25 & 25 & 6,00 & 6,00 & 6,00 & 6,00 & 6,00 & 6,00 & 8,95 & 6,00 & 8,80 \\
\hline 26 & 26 & 6,00 & 6,00 & 6,00 & 6,00 & 6,00 & 6,00 & 27,30 & 6,00 & 8,91 \\
\hline 27 & 27 & 6,00 & 6,00 & 6,00 & 6,00 & 6,00 & 6,00 & 26,53 & 6,00 & 8,33 \\
\hline 28 & 28 & 6,00 & 6,00 & 6,00 & 6,00 & 6,00 & 6,00 & 25,72 & 6,00 & 8,33 \\
\hline
\end{tabular}


Penentuan waktu optimum produksi metabolit sekunder isolat bakteri Actinomycetes dari tanah rhizosfer akar tanaman jarak pagar (Jatropha curcas $L$ ) terhadap bakteri patogen
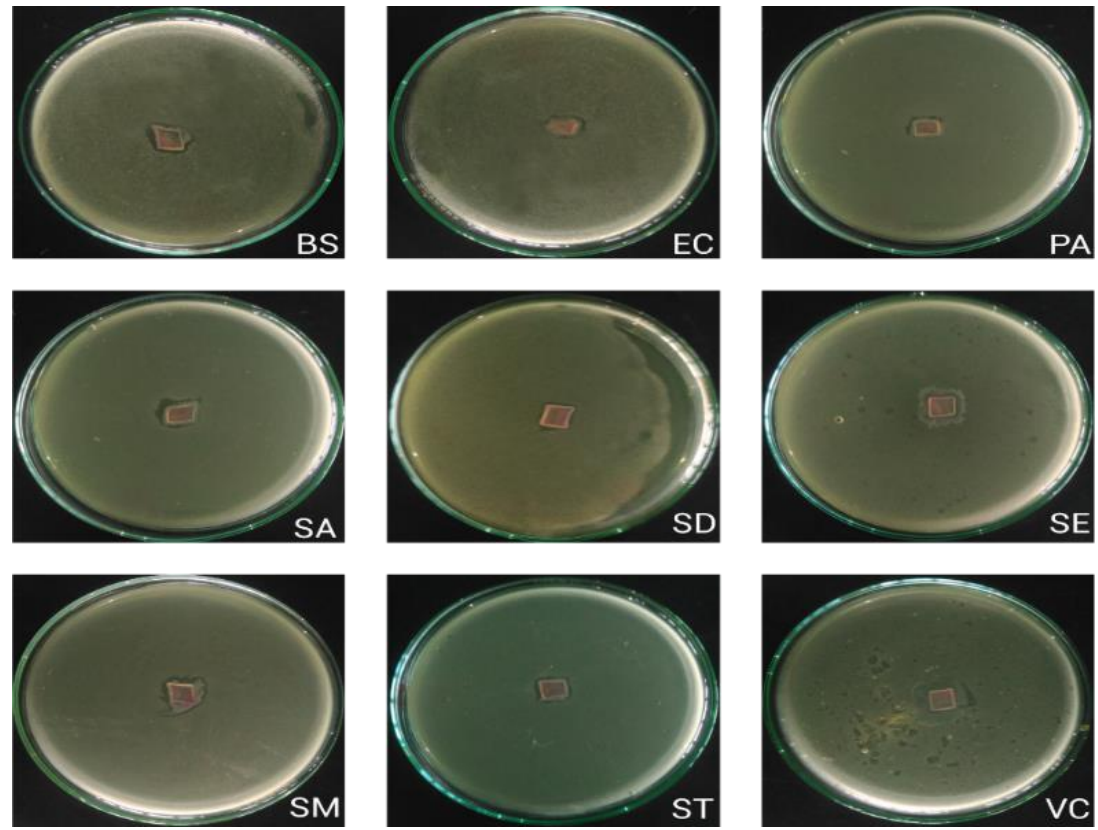

Gambar 1. Foto hasil uji skrining isolat bakteri Actinomycetes terhadap bakteri patogen

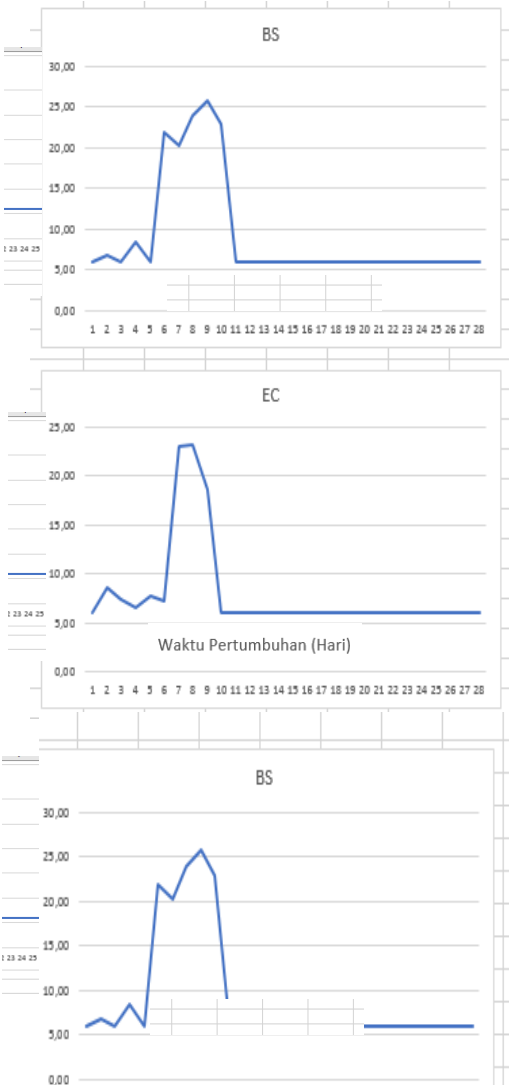

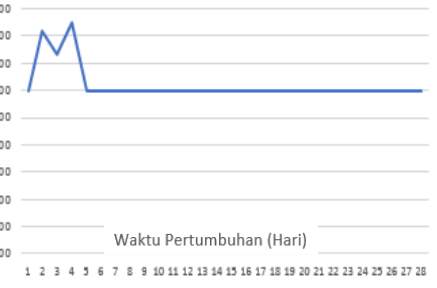

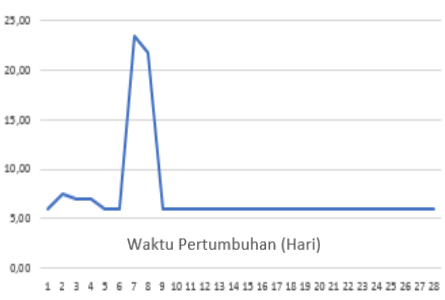

SA

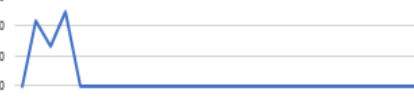

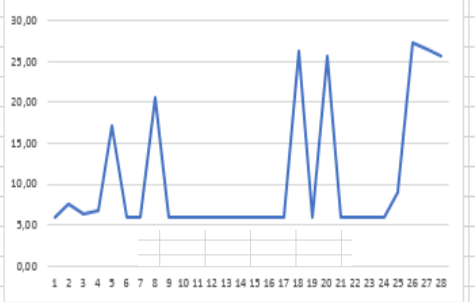

ST

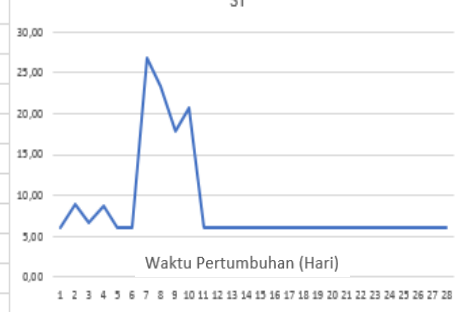

SM

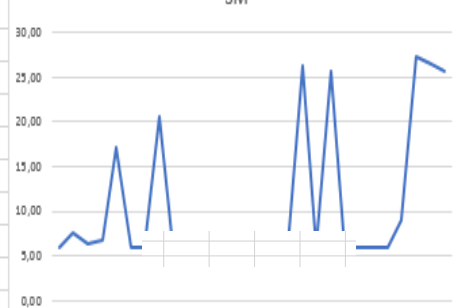

Kurva 1. Penentuan waktu optimum produksi metabolit sekunder isolat bakteri Actinomycetes IBPT 01 
Penentuan waktu optimum produksi metabolit sekunder isolat bakteri Actinomycetes dari tanah rhizosfer akar tanaman jarak pagar (Jatropha curcas $L$ ) terhadap bakteri patogen

PEMBAHASAN

Penelitian mengenai isolasi

bakteri Actinomycetes dari tanah rhizosfer akar tanaman jarak pagar (Jatropha curcas L.) yang berasal dari Kecamatan Patalassang Kabupaten Takalar telah dilakukan. Hasil dari isolasi tersebut diperoleh 2 isolat yang aktif terhadap bakteri patogen dengan kode IBPT 01 dan IBPT 04. Untuk isolat bakteri Actinomycetes dengan kode IBPT 04 aktif terhadap beberapa bakteri patogen dan memiliki waktu produksi optimum pada hari ke 18 terhadap beberapa bakteri patogen, sedangkan isolat bakteri Actinomycetes dengan kode IBPT 01 belum diketahui aktivitasnya terhadap beberap bakteri patogen. Sehingga penelitian ini bertujuan untuk mengetahui aktivitas antibakteri isolat bakteri Actinomycetes kode IBPT 01 terhadap beberapa bakteri patogen penyebab penyakit dan waktu optimum yang diperlukan dalam menghasilkan metabolit sekunder berupa senyawa antibiotik.

Isolat bakteri Actinomycetes kode IBPT 01 yang telah dimurnikan kemudian dilanjutkan dengan melakukan uji skrining terhadap bakteri patogen. Uji skrining ini bertujuan untuk melihat isolat bakteri Actinomycetes tersebut mampu memberikan aktivitas antibakteri dengan terbentuknya diameter zona hambatan di potongan isolat yang diletakkan diatas medium Starch Casein Agar (SCA). Hasil dari uji skrining isolat bakteri Actinomycetes kode IBPT 01 terhadap bakteri patogen dapat dilihat pada Gambar 1 dan Tabel 1.

Menurut Morales et al (2003) aktivitas antibakteri berdasarkan zona hambatannya dapat dikategorikan menjadi 4 , yakni $<6 \mathrm{~mm}$ (tidak ada aktivitas), 6-10 mm (lemah), 11-20 mm (sedang), dan kuat (>21 mm). Berdasarkan hasil penelitian diperoleh bahwa isolat bakteri Actinomycetes kode IBPT 01 memberikan aktivitas antibakteri dengan kategori sedang yang memiliki diamter hambatan 11- 20 $\mathrm{mm}$ terhadap bakteri Bacillus subtilis, Escherichia coli, Pseoudomnas aeruginosa, Staphylococcus aureus, Staphylococcus epidermidis, Shigella dysentriae, Salmonella thypii dan Vibrio cholerae sedangkan terhadapa bakteri Streptococcus mutans dengan diameter $>20 \mathrm{~mm}$ termasuk kategori kuat. Pada uji skrining ini isolat bakteri Actinomycetes memberikan aktivitas terhadap semua bakteri uji.

Setelah dilakukan pengujian skrining antibakteri kemudian dilanjutkan dengan penentuan waktu optimum dalam memproduksi metabolit 
Penentuan waktu optimum produksi metabolit sekunder isolat bakteri Actinomycetes dari tanah rhizosfer akar tanaman jarak pagar (Jatropha curcas $L$ ) terhadap bakteri patogen

sekunder untuk memperoleh senyawa berupa antibiotika. Waktu optimum produksi metabolit sekunder isolat bakteri Actinomycetes IBPT 01 ditentukan dengan waktu pertumbuhan yang difermentasi dengan media fermentasi selama 28 hari dan pengujian aktivitas antibakteri setiap waktu produksi 24 hari atau setiap hari yang dimulai dari hari ke-1 sampai hari ke-28. Hasil penentuan waktu optimum produksi metabolit sekunder dari isolat bakteri Actinomycetes terhadap bakteri patogen dapat dilihat pada tabel 2 dan kurva 1.

Hasil optimasi diperoleh bahwa isolat bakteri Actinomycetes mampu memproduksi metabolit sekunder pada hari ke-9 terhadap bakteri Bacillus subtilis, hari ke-8 terhadap bakteri Escherichia coli dan Staphylococcus epidermidis, hari ke-7 terhadap bakteri Pseudomonas aeruginosa, Salmonella thypii, Vibro cholerae dan Shigella dysentriae, hari ke-4 terhadap bakteri Staphylococcus aureus, hari ke-26 terhadap Streptococcus mutans. Waktu optimum yang dihasilkan oleh isolat Actinomycetes IBPT 01 terhadap bakteri patogen merupakan fase stationer yang ditandai terbentuknya metabolit sekunder.

\section{KESIMPULAN}

Berdasarkan hasil penelitian yang telah dilakukan maka dapat disimpulkan bahwa isolat bakteri Actinomycetes IBPT 01 dapat memberikan aktivitas terhadap 9 bakteri patogen. Waktu optimum produksi metabolit sekunder oleh isolat bakteri Actinomycetes IBPT 01 terhadap bakteri patogen memiliki perbedaan yaitu hari ke-4, hari $k-7$, hari ke-8, hari ke-9 dan hari ke-26.

\section{DAFTAR PUSTAKA}

1. Pratiwi ST. Mikrobiologi farmasi. Yogyakarta : Fakultas Farmasi, Universitas Gadjah Mada, 2008.

2. Budiyanto M, Muhtadi F. Peranan bakteri Actinomycees dalam industri antibiotik. Journal online Biosains. 2012; 1.

3. Husaepa I. Penentuan waktu optimum produksi antibiotika dari isolat Actinomycetes tanah rizosfer tanaman jarak pagar (Jatropha curcas L) dari Kabupaten Takalar (Skripsi). Makassar: Fakultas Farmasi, Universitas Muslim Indonesia, 2017.

4. Amin $M$, Utam $N$, Satria $H$. Fermentasi Hidrolisat Onggok dengan Menggunakan Endofotok (Skripsi). Lampung : FMIPA Universitas Lampung, 2013.

5. Asmi N. Uji Aktivitas antibakteri ekstrak etil asetat fermentat Actinomyces dari tanah merah Kabupaten Luwu Utara secara KLTBioautografi (Skripsi). Makassar : Fakultas Farmasi, Universitas Muslim Indonesia, 2012. 
Penentuan waktu optimum produksi metabolit sekunder isolat bakteri Actinomycetes dari tanah rhizosfer akar tanaman jarak pagar (Jatropha curcas $L$ ) terhadap bakteri patogen

6. Herlina R, Waahyono YBM, Alam G. Purifikasi dan Karakterisasi Senyawa Antibakteri Dari Actinomycetes Asosiasi Spons Terhadap Bakteri Patogen Resisten (Skripsi).Makassar : Fakultas Farmasi, Universitas Hasanuddin, 2010.
7. Sulstyani N, Narwanti I. Aktivitas cairan kultur bakteri penghasil antibiotik (Isolat P301) terhadap Staphylococcus aureus ATCC 25923 dan optimasi waktu produksi metabolit sekunder (Skripsi) Jogjakarta : Fakultas Farmasi Ahmda Dahlan, 2015. 